\title{
Baltijos valstybių užsienio ir saugumo politikos europeizacijos tendencijos
}

\begin{abstract}
Straipsnyje méginama pažvelgti į Baltijos valstybių užsienio ir saugumo politiką (USP) per europeizacijos koncepcijos prizmę. Siejant europeizaciją su lojalumu ES normoms bei europinès tapatybės konstravimu, nagrinèjama ES įtaka Baltijos valstybių USP, joms siekiant narystės ir tapus ES narèmis. Kelyje į ES Baltijos valstybių užsienio ir saugumo politikos europeizacija iš esmès vyko viena kryptimi - iš viršaus į apačią (iš centro ị tautines valstybes); tai buvo veikiau pragmatinis, o ne vertybinis Baltijos valstybių užsienio ir saugumo politikos bei BUSP tikslų suartëjimas. Kita vertus, šiuo laikotarpiu išryškèjo ir nacionalinė europeizacijos projekcija - Europos Sajungos reikalavimai panaudojami kaip apsauginis skydas, pateisinant nepopuliarius ir vidaus, ir užsienio politikos sprendimus. Baltijos valstybėms tapus ES narėmis, pragmatinė ES interpretacija išlieka, tačiau sustiprëja valstybiu pastangos daryti poveikį ES bendrai užsienio ir saugumo politikai, perkeliant nacionalinius interesus į ES lygị. Baltijos valstybių užsienio ir saugumo politikoje tarsi iškreiptame veidrodyje atsispindi ES BUSP nenuoseklumas, susijęs su ES kaip specifinio politinio objekto neapibrèžtumu. Tam tikra prasme Baltijos valstybių užsienio ir saugumo politika yra nuoseklesnė negu Europos Sajungos. ES kaimynystès ir Rytų partnerystės politikoje jos pabrèžia ne pragmatini, o normatyvinį aspektą, ragindamos rimtai traktuoti Europos vertybinius pagrindus.
\end{abstract}

\section{Ivadas}

Baltijos valstybės priklauso gana specifiniam Baltijos Šiaurès regionui, kurio pagrindinè geopolitinė dominantė ilgą laiką buvo Rusija(Sovietų Sąjunga). Suvaidinusios Sovietų Sąjungos žlugimo katalizatoriaus vaidmenį, o po to sèkmingai įveikusios pagrindinius demokratinès valstybès atkūrimo etapus ir pasukusios integracijos į Vakaru saugumo bendruomenę keliu, jos savo pastarujų metų istorijoje ịkūnija esmines posovietinės Europos politinès transformacijos tendencijas. Po nepriklausomybès atkūrimo Baltijos valstybės pirmuosius žingsnius santykiuose su ES ir NATO žengè 1990-1991 metais ${ }^{1} .2004$ metais jos tapo ES ir NATO narèmis. Pirmoji jụ "grįžimo į Europą" stadija buvo baigta. Kaip rašė žurnalas The Economist: „nuo 1989 metu iš visų stulbinančiu, Europos žemėlapi pakeitusių transformaciju, Baltijos valstybiu perẻjimas nuo

\footnotetext{
* Prof. dr. Gražina Miniotaite - Lietuvos karo akademijos Politikos mokslų katedros profesorè. Adresas korespondencijai: Šilo g. 5a, 10322 Vilnius, tel. (8 5) 210 3569, el. paštas: grazina.m@gmail.com ${ }^{1}$ ES-Baltijos valstybių santykiai neprasidejjo tuščioje vietoje. Šaltojo karo metais buvo nemažai neformalių kontaktų tarp ES institucijų ir neoficialių Baltijos valstybių atstovų (daugiausiai tai buvo emigrantai, palikę savo šalis prieš II pasaulinį karą arba po jo). Žr. Lasas A., „,Guilt, Sympathy, and Cooperation: EU-Baltic Relations in the Early 1990s“, East European Politics and Societies 22 (2), p. 347-372.
} 
sovietinès priklausomybės prie narystės svarbiausiuose Vakarų klubuose yra pati nuostabiausia“"2.

Paprastai analizuojant pokyčius pokomunistinėse valstybėse tiriama ju trilypè transformacija, t.y. valstybingumo įtvirtinimas, dažniausiai siejamas su tautinès valstybès kūrimu, demokratizavimas bei rinkos ekonomikos vystymas ${ }^{3}$. Aiškinantis naujausias pokomunistinių valstybių kaitos tendencijas, vis daugiau dèmesio skiriama ketvirtajam analizès matmeniui -jų santykiams su tarptautinèmis organizacijomis, apibrèžiamam kaip „,naujų arba atkūrusių nepriklausomybę valstybių integravimasis į tarptautinę sistemą, kuriai būdinga tarpusavio priklausomybè $\dot{e}^{\prime \prime 4}$. Analizuojant tokių organizacijų kaip Pasaulio bankas, Tarptautinis valiutos fondas, NATO, ES ir kitų vaidmeni, ieškoma atsakymo į klausimą - kokią įtaką tarptautiniai veikëjai daro valstybių vidaus ir užsienio politikai ir kur yra šio poveikio ribos? ${ }^{5}$. Šio straipsnio dėmesio centre-ES įtaka Baltijos valstybių užsienio ir saugumo politikai, traktuojamai kaip valstybès tarptautinès tapatybės konstravimo priemoné ${ }^{6}$. Taip pat jame mėginama atsakyti į klausimą ar, savo ruožtu, Baltijos valstybės daro įtaką ES bendrai užsienio ir saugumo politikai. Nagrinëjant šiuos klausimus, straipsnyje bus mėginama pažvelgti į Baltijos valstybių užsienio ir saugumo politiką per ju europeizacijos proceso prizmę. Straipsnį sudaro trys dalys. Pirmoje dalyje nagrinèjama europeizacijos ir užsienio bei saugumo politikos santykis, antroje - ES įtaka Baltijos valstybių užsienio politikai iki narystès šioje organizacijoje, trečioje - tapus ES narėmis. Nepaisant Baltijos valstybių užsienio ir saugumo politikos panašumu, mėginama jas nagrinèti kaip atskirus tarptautinés politikos veikëjus (actors) nors kai kuriais atvejais jos veikia kaip vieningas politinis veikëjas - Baltijos valstybès.

\section{Baltijos valstybès ir europeizacija}

Baltijos valstybiu politiniame diskurse po nepriklausomybės atkūrimo iš pat pradžių išryškèjo dvi pagrindinès valstybès kūrimo sampratos: restauracinė ir integracinè. Pirmoji valstybingumą sieja su prieškarinès tautinès valstybès pagrindinių vertybinių ir geopolitinių nuostatų rekonstrukcija, antroji orientuojasi į kosmopolitinę integruotą Europą, i̇ tapimą „normalia“ vakarietiška valstybe. Šis dvilypumas Baltijos valstybių užsienio politikoje reiškiasi kaip įtampa tarp tautinès valstybės tapatybės konstravimo ir integracinių užsienio politikos praktiku . Tautinès valstybès tapatybė reikalauja atskirties (exclusion),

\footnotetext{
2 "The Balts and the European Union", The Economist (print edition, 12 December 2002), http://www. economist.com/agenda/displayStory.cfm?Story_id=1490390, 20012011

${ }^{3}$ Offe C., „Designing Institutions in East European Transitions“ in Goodin R. E., ed., The Theory of the Institutional Design, Cambridge: Cambridge University Press, 1998, p. 199-226.

${ }^{4}$ Orenstein M., Bloom S., Transnational Actors in Central and East European Transition, Pittsburg, PA: University of Pitsburg Press, 2008, p. 2-3.

${ }^{5}$ Ten pat, p. 3.

${ }^{6}$ Campbell D., Writing Security: United States Foreign Policy and the Politics of Identity, Manchester: Manchester University Press, 1992.

${ }^{7}$ Miniotaite G., "The Baltic States: In Search of Security and Identity" in Krupnick Ch.,ed., Almost NATO: Partners and Players in Central and Eastern European Security, Lanham, Md.:Rowman \& Littlefield, 2003, p. 261-296.
} 
arba suvereniteto, politikos, o pagrindinis užsienio politikos tikslas - „grįžimas į Europą" arba į Vakarų saugumo bendruomenę-įtraukties (inclusion), arba integracijos, politikos, siejamos su šalių normatyvine europeizacija. Remiantis Douglas'u Brommessonu, normatyvinè europeizacija yra apibrèžiama kaip hierarchinis Europos centro normu plètros procesas, kurio metu valstybės kandidatès ir narès igyja įsipareigojimus centrui bei pakinta jų normatyvinis išeities taškas Formuojasi europinè tapatybe், kuriai būdingas valstybės lojalumas europinėms normoms bei įsipareigojimas jas ginti nuo išorinio poveikio ${ }^{8}$. Kita vertus, europeizacija - tai ne tik iš viršaus (iš centro) nustatytų normu igyvendinimas, bet ir procesas, kurio metu valstybės narės naudoja ES kaip įrankị perkelti nacionaliniams interesams i europinį lygi ${ }^{9}$. Paprastai iš viršaus duotų normų ịgyvendinimas siejamas su nedidelèmis naujomis valstybèmis, o instrumentinis ES traktavimas - su didžiosiomis įtakingomis valstybèmis. Viršaus ir apačios, t.y. centro normų ir valstybès narès interesų suderinimo priemonès vaidmenį atlieka ES bendra užsienio ir saugumo politika (BUSP). ES valstybių narių ir BUSP santykyje viršus ir apačia susilieja - tai procesas, priklausantis ir nuo Briuselio direktyvu, ir nuo valstybės narès užsienio politikos vizijų ir tikslų (1 lentelè).

1 lentelè. Europeizacija ir nacionalinè užsienio ir saugumo politika

\begin{tabular}{|c|c|c|}
\hline & Europeizacija & $\begin{array}{c}\text { Nacionalinė užsienio ir saugumo } \\
\text { politika }\end{array}$ \\
\hline I. & $\begin{array}{l}\text { Europos Sajungos projekcija (iš viršaus) } \\
\text { Adaptacija ir politikos suartèjimas } \\
\text { Valstybės narès prisiderinimas prie ES } \\
\text { narystės reikalavimu }\end{array}$ & $\begin{array}{l}\text { Didejjanti politinė centro įtaka } \\
\text { Bendrų tikslų prièmimas } \\
\text { Bendros politikos viršenybė } \\
\text { ES normų ir politikos internalizacija }\end{array}$ \\
\hline II. & $\begin{array}{l}\text { Nacionalinè projekcija } \\
\text { (iš apačios) } \\
\text { Nacionalinès valstybès įtaka ir indèlis } \mathfrak{i} \\
\text { BUSP }\end{array}$ & $\begin{array}{l}\text { Valstybė siekia padidinti savo itaką } \\
\text { pasaulyje } \\
\text { Valstybė siekia daryti įtaką kitų ES } \\
\text { valstybiu užsienio politikai } \\
\text { Valstybė naudoja ES kaip apsaugini } \\
\text { skydą, kad pateisintu nepopuliarius } \\
\text { užsienio politikos žingsnius. } \\
\text { Perkèlimas nacionalinės užsienio } \\
\text { politikos tikslu i ES lygi }\end{array}$ \\
\hline
\end{tabular}

Šaltinis: Reuben Wong (2007) ir Fredrick Lee-Ohlsson (2009) ${ }^{10}$

\footnotetext{
${ }^{8}$ Brommesson D., ,Normative Europeanization: the Case of Swedish Policy Reorientation', Cooperation and Conflict: Journal of the Nordic International Studies Association 45 (2), 2010, p. 228.

${ }^{9}$ Wong R., „The Europeanization of Foreign Policy“ in Hill Ch., Smith M., eds., International Relations and the European Union, Oxford: Oxford University press, 2005, p. 134-153).

${ }^{10}$ Wong R., „Foreign Policy“ in Graziano P., Vink M. P., eds., Europeanization: New Research Agendas, Houndmills: Palgrave Macmillan, 2007, p. 326; Lee-Ohlson F., „Sweden and Development of the European Security and Defence Policy: A Bi-Directional Process of Europeanization“, Cooperation and Conflict 44 (2), 2009, p. 126.
} 
Europeizacija užsienio politikoje nėra pasyvus procesas, tai integracijos (adaptacijos) ir nacionalinės diferenciacijos santykis, kitais žodžiais - įtraukties ir atskirties sąveika. Baltijos valstybių santykiuose su Europos Sajunga galima pastebèti ir įtraukties (inclusion) ir atskirties (exclusion) tendencijas. Jos gana tiesiogiai susiję su Europos interpretavimo ypatybėmis ju politiniame diskurse. Siekdamos tapti ES narèmis, Baltijos valstybės Europą traktavo kaip tautiniu valstybių bendriją, kurių saugumą užtikrina NATO. Kaip pažymi M. Marcussenas ir K. Roscheris, šį Europos įvaizdi paprastai „įdarbina“ tos valstybès, kurios orientuojasi ị liberalų tautinę tapatybę. Pastarajam yra būdingas „Mes" apsiribojimas sava tauta ir valstybe ${ }^{11}$. Neatsitiktinai Baltijos valstybių užsienio ir saugumo politika, siekiant narystės ES, buvo orientuota į nacionalinį saugumą, šauktinių kariuomene grindžiamą teritorinę gynybą bei tautinės valstybės tapatybės konstravimą. Tapus ES naremis, Baltijos valstybiu politiniame diskurse vis svaresnis vaidmuo tenka Europos kaip normatyvinès galios sampratai ${ }^{12}$. Tai koreguoja jų užsienio politiką, jos siekia tapti normatyvinès galios dalimi. Pamėginsime išplėtoti šią Baltijos valstybių sąveikos su ES interpretaciją.

\section{Baltijos valstybių užsienio politika kelyje ị Europą}

Vakarų valstybių atsaku i iš esmės beveik visų posovietinės erdvės valstybių siekimą narystės ES ir NATO buvo bendrų narystės kriterijų paskelbimas, kurie yra žinomi kaip Kopenhagos kriterijai (1993 m.) ir NATO plètros studija (1995 m.). Kriterijai buvo papildyti jų igyvendinimo kontrolès ir įvertinimo mechanizmų sukūrimu. Narystės NATO ir ES siekimo procesas tampa Baltijos valstybių kūrimo pagal Vakarų demokratijos modeli procesu, reikalaujančiu esminiu politinių ir ekonominių reformų bei pokyčių užsienio bei saugumo ir gynybos politikoje.

Europos Sajunga ir NATO gali būti apibūdintos kaip konstitutyvios institucijos, kurios pateikdamos valstybės narès charakteristikas ir tikslus vyriausybėms, įneša svarų indėli apibrèžiant veikẻju (actors) tapatybes, vertybes ir interesus. Kaip pažymi Frankas Schimmelfennigas, ES pagrindas yra postnacionalistinè, liberalioji tapatybė, kurios kultūrinis turinys apsiriboja politine kultūra. Atitinkamai ES suteikia narystę toms valstybėms, kurios priima jos liberalias vertybes ir kurios tvirtai laikosi jos liberaliu normu, t. y asmens laisvės, pilietinių laisvių ir politinių teisių ${ }^{13}$. Taigi ES plètra į rytus yra

\footnotetext{
${ }^{11}$ Marcussen M., Roscher K., „,The Social Construction of “Europe”: Life- Cycles of Nation-State Identities in France, Germany and Great Britain" in Strath B., ed., Europe and the Other and Europe as the Other, Bruxelles: PIE Lang, 2000, p. 333-334.

${ }^{12}$ Miniotaitė G., „Europos normatyvinè galia ir Lietuvos užsienio politika“, Politologija 43 (3), 2006, p. $3-19$.

${ }^{13}$ Schimmelfennig F., "Liberal identity and Postnationalist Inclusion: The Eastern Enlargement of the European Union" in Cederman L., Constructing Europe's identity: the external dimension, Boulder London: Lynne Rienner Publishers, 2001, p. 172.
} 
grindžiama sąlygiškumo principu. Panagrinėkime, kokie pokyčiai įvyko Baltijos valstybėse, mėginant atitikti narystės kriterijus? Kaip ES narystės siekimas paveikè ju politinę tapatybę bei užsienio ir saugumo politiką?

Po Rusijos kariuomenès išvedimo 1993-1994 metais ${ }^{14}$ vakarietiška Baltijos valstybių užsienio politikos kryptis ígavo negrįžtamą pobūdį. Pagrindiniais užsienio politikos tikslais tampa geri santykiai su kaimynais ir narystė ES ir NATO. Nors ir siekdamos tų pačių tikslu, Baltijos valstybės veikė atskirai, kaip konkurentės pabrèždamos savo geografinị ir istorinị išskirtinumą ${ }^{15}$. Tuo metu ju politinè tapatybė igauna geografinį apibrèžtumą. Estija savo pagrindine partnere kelyje į ES laiko Suomiją. Jos prezidento ir kitų oficialiu pareigūnu kalbose įsitvirtina Estijos kaip Šiaurès valstybès tapatybe ${ }^{16}$. Lietuvos politikai, po to, kai 1997 metais Lenkija igavo valstybès - NATO kandidatès statusą ir tapo pripažinta Lietuvos strategine partnere, apibrèžè Lietuvą kaip Centrinès Europos arba Centrinès Europos Baltijos valstybę. Latvija, įsiterpusi tarp Estijos ir Lietuvos, kur kas labiau negu jos kaimynès siekè glaudesnio Baltijos ir plačiau - Baltijos jūros regiono valstybių bendradarbiavimo ${ }^{17}$. Ji save identifikavo kaip Šiaurès Baltijos arba Baltijos jūros valstybę. Šis iš pirmo žvilgsnio nuostabą keliantis geografinis Baltijos valstybių susipriešinimas buvo svarbi jų kaip tautinių valstybiư, siekiančių "grịžti į Europą", savivokos dalis.

Kaip pažymi Klausas Ederis, istoriškai Europos erdve pasidalijo išilgai specifinių socialinių ašių. Tai Šiaurès-Pietų ir Vakarų-Rytų ašys, siejamos su technine bei socialine pažanga ir su atsilikimu. Europos šiaurès vakarai asocijuojasi su pažanga, pietryčiai - su atsilikimu. Ši normatyvinė Europos slinktis i šiaurès vakarus prasidèjo 17 amžiuje kartu su sekuliarizacija ir instituciniu demokratijos idejju igyvendinimu. Senąją civilizuotą Pietu Europą pradejjo išstumti naujoji necivilizuota Šiaurè - anglosaksai ir Skandinavijos valstybès. Metaforiškai galima teigti, kad Europos pietūs yra jos siela, šiaurès vakarai $\operatorname{protas}^{18}$. Socialinė Europos geografinès erdvės diferenciacija turi ne tik erdvinę, bet ir laiko dimensiją. Siaurès vakarai yra greitesni, pietryčiai - lètesni. Šiame kontekste Europos integracija gali būti traktuojama kaip mėginimas neutralizuoti skirtingus senosios Europos greičius bei sinchronizuoti jos raidą erdvëje ir laike. Estija, siedama save su Šiaure, pasirinko racionalu, pragmatini, greitą kelią i Europą. O Lietuva pasuko į pietus ne tik dèl strateginės partnerystės su

\footnotetext{
${ }^{14}$ Rusijos kariuomenè iš Lietuvos buvo išvesta 1993 metų rugpjūčio mènesi, iš Estijos ir Latvijos - metais vèliau.

${ }^{15}$ Užsienio politikoje tai pasireiške kaip nesutarimai dèl jūros sienos nustatymo tarp Estijos ir Latvijos ir Lietuvos ir Latvijos. Jūros sienos sutartis tarp Lietuvos ir Latvijos buvo pasirašyta tik 1999 metais, tačiau Latvija jos dar nèra ratifikavusi.

${ }^{16}$ Estijos užsienio reikalų ministras Tomas Ilves 1998 metais pareiškè: Aš matau, kad ne vienerius metus Estija nukenčia nuo nepakankamai gerai apgalvotos kitų Baltijos valstybiu politikos. Estija yra pokomunistinè Šiaurès valstybė, o ne Baltijos valstybe்“. Cituojama pagal: Ozolina Z., „The Impact of the European Union on Baltic Cooperation“", COPRI Working Papers 3, 1999, p. 15.

${ }^{17}$ Pozityvų Latvijos požiūrị i Baltijos valstybiu bendradarbiavimą iliustruoja Baltijos vienybès judèjimo ikūrimas 1997 metais.

${ }^{18}$ Eder K., „The Two Faces of Europeanization: Synchronizing a Europe moving at varying speeds“, Time \& Society 13(1), 2004, p. 101.
} 
Lenkija, bet ir siekdama "grižžti į namus" kaip sena civilizuota Europos valstybė. Latvija yra artimesnè Estijai negu Lietuvai. Ši skirtinga Baltijos valstybiu erdvinè savivoka atsispindi jų užsienio ir saugumo politikoje kaip pasirinkimas tarp pragmatizmo ir idealizmo nuostatų.

Šalia geografinès tapatybès formuojasi ir tarptautinè (funkcinè) Baltijos valstybiu tapatybe், kuri konstruojama priklausomai nuo to, kaip jos mato savo vaidmenį naujoje jų idejjinės lokalizacijos vietoje - Europoje, arba plačiau - Vakaruose. Tarptautinę tapatybę sudaro kintantis naratyvas, kuriuo yra pagrindžiama valstybès vieta ir vaidmuo tarptautinejje sistemoje.

Tarptautinè tapatybė daugiausia susijusi su Baltijos valstybiu požiūriu ir santykiais su visoms bendra kaimyne Rusija, svarbia tarptautinès politikos veikëja. Po nepriklausomybės paskelbimo Baltijos valstybės traktavo save kaip tiltą tarp Rytų (Rusijos) ir Vakarų (Europos), kaip „kontaktų žemę“. Užsienio politikoje tokią tarptautinės tapatybès sampratą atitiko plačiai diskutuota, tačiau niekada neigyvendinta neutraliteto politika. Valstybès - tilto metaforos ir su ja susijusios neutraliteto idejos buvo atsisakyta 1994-1995 metais, kai pagrindiniu užsienio ir saugumo politikos tikslu tapo narystė NATO ir ES. Ją pakeitè valstybės - Vakaru civilizacijos placdarmo metafora ${ }^{19}$. Baltijos valstybių - Vakaru placdarmo įvaizdi geriausiai atitiko Europos, kaip Vakarų bendruomenės sudedamosios dalies, įkūnijančios krikščioniškąsias vertybes, samprata. Šiai sampratai sustiprinti dažnai buvo pasitelkiama Samuelio Huntingtono civilizacijų konflikto idẻja, ypač Estijoje. Baltijos valstybės traktavo save kaip sieną, skiriančią Vakaru civilizaciją nuo nevakarietiškos Rusijos.

Nuo 1997 metu, ryškëjant Baltijos valstybiu perspektyvai tapti ES narèmis $^{20}$, ju tapatybės konstravimo procese atsirado Baltijos valstybiu kaip Europos avanposto motyvai ${ }^{21}$. Buvo pabrèžiama, kad Baltijos valstybės santykiuose su posovietine erdve skleidžia Europos vertybes ir normas, tapdamos jos atstovėmis. Užsienio politikoje avanposto tapatybẻ buvo institucionalizuota dalyvaujant ES Šiaurès dimensijos veikloje bei ES rytu politikoje. Buvo tikimasi, kad Šiaurès dimensija „,padès Estijai Latvijai ir Lietuvai prisitaikyti prie naujo centrinio veikejo vaidmens vystant bendradarbiavimą tarp ES, Rusijos ir artimų NVS šalių" 22 .

Apžvelgta tarptautinės Baltijos valstybiu tapatybės kaita neapsiriboja žongliravimu metaforomis, ji netiesiogiai parodo priartëjimo prie Europos laipsnį ir yra tiesiogiai susijusi su pokyčiais santykiuose su Rusija. Būtent santykiuose su Rusija labiausiai pasireiškia ES įtaka Baltijos valstybių užsie-

\footnotetext{
${ }^{19}$ Kuus M., „,Toward Cooperative Security? International Integration and the Construction of Security in Estonia“, Millennium: Journal of International Studies 31(2), 2002, p. 297-317.

${ }^{20} 1997$ metų liepos mėnesi Europos Komisija patvirtino „Darbotvarkę 2000“. Estija buvo pakviesta pradèti derybas dèl narystės su ES 1997 metais, Latvija ir Lietuva - 1999 metais.

${ }^{21}$ Pavlovaite I., "Paradise Regained: The Conceptualization of Europe in the Lithuanian Debate" in Lehti M., Smith D.J., eds., Post-Cold War Identity Politics: Northern and Baltic Experiences, London: Frank Cass, 2003, p. 214.

${ }^{22}$ Ojanen H., "Enlargement: A Permanent Threat for EU, and a Policy Problem for Finland", Northern

Dimension Yearbook, Forssa: The Finnish Institute of International Affairs, 2001, p. 29.
} 
nio politikai. Rusija yra ne tik Baltijos valstybiu kaimynė, bet ir strateginė ES partnerè, svarbi ES energetinių išteklių tiekejja. Pvz., tokios ES valstybės kaip Vokietija ir Prancūzija, turi ilgalaikes ir gilias bendradarbiavimo su Rusija tradicijas.

Baltijos valstybės taip pat turi ilgą santykių su Rusija patyrimą, kuris iš esmès skiriasi nuo europietiško. Tai ilgas gyvavimas Rusijos imperijos sudètyje $^{23}$, trumpas nepriklausomybès atokvėpis 1918-1940 metais, vèliau beveik 50 Sovietų Sajungos okupacijos metu (1944-1991). Pastarasis laikotarpis buvo ypač destruktyvus ne tik Baltijos valstybiu valstybingumui, bet ir ju tautinei tapatybei bei gyventoju mentalitetui. Dèl Baltijos valstybiu gyventoju deportaciju i ̨ Sibirą, karo ir pokario ginkluoto pasipriešinimo praradimu gerokai pakito gyventojų demografinė sudètis, ypač Latvijoje ir Estijoje. Per sovietini laikotarpį Estija ir Latvija tapo daugiatautėmis valstybėmis ${ }^{24}$.

1991 metais atkūrus nepriklausomybę, buvo baiminamasi ne tik tiesioginès Rusijos agresijos, bet ir jos destruktyvios ekonominès bei politinės įtakos, pasinaudojant rusakalbiais gyventojais. Estijos ir Latvijos politikai juose matė "penktają koloną", galinčią sugriauti valstybę iš vidaus ${ }^{25}$. Turbūt tuo galima paaiškinti, kad 1991 metais Latvijoje ir 1992 metais Estijoje buvo priimti sovietinès okupacijos metais atvykusiems rusakalbiams nepalankūs pilietybès įstatymai, pagal kuriuos tik tarpukario (1918-1940) Estijos ir Latvijos valstybiu gyventojai ir ju palikuonys turëjo teisę į pilietybę. Kiti, apsigyvenę okupacijos metais, turèjo pereiti sudètingą natūralizacijos procedūrą. Lietuvoje buvo priimtas nulinis pilietybès įstatymas pagal kurį visi įstatymo prièmimo metu Lietuvoje gyvenantys turi teisę i c pilietybę.

Nenuostabu, kad siekiant ES narystès pagrindine problema Estijoje ir Latvijoje tapo politiniai Kopenhagos kriterijai, konkrečiai, reikalavimas gerbti ir saugoti mažumu teises. Iš pirmo žvilgsnio vidaus politikos problema virto tarptautinès politikos klausimu, į kurio sprendimą įsitraukẻ ESBO, Europos Komisija, Europos Taryba, Jungtinès Tautos ir, žinoma, Rusija. Patirdamos „adaptacinį ES spaudimą“26, Estija ir Latvija keitè pilietybės įstatymus atitikimo europinėms normoms kryptimi ${ }^{27}$. Tačiau, reikia pažymėti, kad šie pokyčiai ir šiandien netenkina Rusijos lūkesčių.

Narystės ES ir NATO siekimas taip pat turëjo įtakos sprendžiant Baltijos valstybiu ir Rusijos sienos sutarčių klausimus. Estija ir Latvija siekè, kad ju

\footnotetext{
${ }^{23}$ Estija ir Latvija buvo Rusijos imperijos sudedamosios dalys 1721-1915, Lietuva - 1795-1915 metais.

${ }^{24}$ Per sovietini laikotarpi rusų tautybės gyventojų skaičius Latvijoje išaugo nuo 8,8 (1935) iki 34 procentu (1991), Estijoje - nuo 8 iki 30 procentų. Žr. Vares P. ,Zhuryari O., Estonia and Russia, Estonians and Russians: A Dialogue. Tallinn: The Institute of International and Social Studies, 1996, p. 9.

${ }^{25}$ Haab M., "Estonia" in Mouritzen H., ed., Bordering Russia: Theory and Prospects for Europe's Baltic Rim, Aldershot: Ashgate, 1998, p. 109-129.

${ }^{26}$ Maniokas K., Europos Sajungos plètra ir europeizacija, Vilnius: Eugrimas, 2003, p. 94.

${ }^{27}$ Kalmus V., "Is Interethnic Integration Possible in Estonia?: Ethno-Political Discourse of Two Ethnic Groups", Discourse Society 14(6), 2003, p. 667-697; Schmid C., Zepa B., "Language Policy and Ethnic Tensions in Quebec and Latvia", International Journal of Comparative Sociology 45 (3-4), 2004, p. $231-252$.
} 
teritorija būtų apibrèžiama pagal 1920 metų taikos sutartis su Rusija ${ }^{28}$, pagal kurias joms priklausè dalis dabartinės Rusijos teritorijos. Artëjant ES ir NATO viršūnių susitikimams, turëjusiems įvertinti Baltijos valstybių atitiktį narystės kriterijams, ir Estija (1996), ir Latvija (1997) atsisakẻ teritorinių reikalavimu Rusijai. Nepaisant to, Estijos ir Rusijos sienos sutartis buvo pasirašyta tik 2005 metais, tačiau ir šiandien neratifikuota Rusijos. Latvija ir Rusija sutartị pasirašè dar vèliau - 2007 metais, tais pačiais metais ji buvo ratifikuota abieju šalių. Lietuva sausumos sienos sutarti pasirašè 1997 metais, Rusija ją ratifikavo tik 2003 metais. Lietuvos-Rusijos santykius temdo ne rusų mažumos teisių klausimai, o Lietuvos energetinio saugumo problemos, susijusios su jos priklausomybe nuo Rusijos energetinių išteklių, bei Rusijos Kaliningrado srities karinio ir civilinio tranzito per Lietuvos teritoriją klausimai. O tautinių mažumų teisių užtikrinimo klausimai epizodiškai iškyla Lietuvos-Lenkijos santykiuose.

Trumpa Baltijos valstybių kelio į ES apžvalga leidžia pažymėti, kad šiuo laikotarpiu ir šių valstybių savęs suvokimas tarptautinëje erdvëje, ir jų užsienio ir saugumo politikos ígyvendinimas neperžengia tautinès valstybès tapatybès ribų su jai būdinga išorinės grèsmès samprata. Pozityvus tapatinimasis su Europa buvo lydimas atsiribojimo nuo ne-Europos, pabrèžiant Rusijos grèsmę. Kita vertus, viešajame diskurse Europa yra suvokiama ne tik kaip Mes dalis, bet ir kaip kultūrinė grèsmė tautinei tapatybei. Ši tendencija išliko ir Baltijos valstybėms pradejus tiesiogines derybas dèl narystès. Harmonizuojant Lietuvos teisę su ES Acquis buvo ne tik keičiami įstatymai, bet ir deramasi dèl išimčių, kurios turëjo pristabdyti europinių normu, ribojančių valstybės suverenitetą, įsigaliojimą ${ }^{29}$.

Iš esmès Baltijos valstybiu užsienio ir saugumo politikos europeizacija vyko viena kryptimi - iš viršaus į apačią (iš centro į tautines valstybes); tai buvo veikiau pragmatinis, o ne vertybinis Baltijos valstybių užsienio politikos ir BUSP tikslų suartëjimas, derinantis prie ES narystès reikalavimų. Siekiant narystės Baltijos valstybių ir vidaus, ir užsienio politika neišvengiamai buvo adaptacinè. Aiškiai suformuluoti narystės reikalavimai bei gerai apgalvotas ju igyvendinimo kontrolès mechanizmas nepaliko ypatingos erdvès kandidačiu iniciatyvai. Suvaržytos įsipareigojimo atitikti Acquis, laiku uždaryti derybinius skyrius ar siekti savo gynybos struktūrų suderinamumo su NATO struktūromis, Baltijos valstybės skyrèsi nebent vieta „pažangumo“ lentelëje. Lietuva buvo tarp pažangiausiujų kelyje i NATO, Estija - i ES. Kita vertus, šiuo laikotarpiu išryškejjo ir nacionalinè europeizacijos projekcija. Europos Sajungos reikalavimai panaudojami kaip apsauginis skydas, pateisinant nepopuliarius vidaus bei užsienio politikos sprendimus (Ignalinos atominès elektrinės uždarymas, vizų įvedimas pasienio gyventojams).

\footnotetext{
${ }^{28}$ Estija, lyginant jos teritoriją su jai priklausiusia pagal 1920 metų Tartu sutartị, prarado apie 2000 kvadratinių kilometrų. Dalis buvusios Latvijos teritorijos pagal 1920 metų Rygos sutarti šiuo metu priklauso Rusijos Pskovo sričiai. Lietuvai 1920 metų sutartis su Rusija nebuvo aktuali. Lyginant su tarpukario laikotarpiu, Lietuvos teritorija išsiplètė: pirmą kartą šalies istorijoje jai priklauso ir Vilnius, ir Klaipėda. ${ }^{29}$ Maniokas K., 26 išnaša.
} 


\section{Baltijos valstybès Europos Sajungoje}

2002 metu pabaigoje Estija, Latvija ir Lietuva kartu su dar penkiomis posovietinės erdvės valstybėmis ir Malta bei Kipru po sẻkmingų derybų buvo pakviestos tapti ES narèmis. ES sprendimas priimti net aštuonias pokomunistinės erdvės valstybes sunkiai galèjo būti paaiškintas instrumentinio racionalumo argumentais. Neatsitiktinai akademiniuose darbuose, analizuojančiuose ES plètrą, atsiranda tokios sąvokos kaip "normatyvine tvarka“" ${ }^{30}$, "bendrijos spąstai“ (the community trap), , ,retorinis veiksmas" (rhetoric action) ${ }^{31}$, ",komunikacinis racionalumas“ , „Europa kaip vertybemis grịsta bendrija“ (,Europe as ,"value-based community $\left.^{\prime \prime}\right)^{32}$ "EB kolektyvinè kaltè ir atsakomybe ${ }^{\text {“33. }}$. Daug dèmesio Europos plètros klausimams skyręs Frankas Shimmelfennigas teigia, kad Europa plètros i rytus politikoje tapo savo pačios konstruojamos normatyvinės tapatybės įkaite: „valstybès, kartą pagautos į bendrijos spąstus, gali būti priverstos šlovinti jos tapatybę ir vertybinius įsipareigojimus “34. Šią mintį iliustruoja Marianne Riddervold ir Helene Sjursen, kurios aktyvią Danijos paramą Baltijos valstybiu narystei ES aiškina jos europinės tapatybės spaudimu ${ }^{35}$.

Aiškinantis, kame slypi ES integruojanti jẻga, kuo ji patraukè tik ką iš „sajungu“" (Sovietų Sajungos, Jugoslavijos Socialistinès Federacinès Respublikos) ištrūkusias ir savo tautinès tapatybẻs ịtvirtinimu susirūpinusias valstybes, akademiniuose tyrimuose vis labiau įsitvirtina normatyvinès galios („,normative power") terminas ${ }^{36}$. I. Mannersas ryškiausiu normatyvinès galios pavyzdžiu laiko Europos Sąjungą. Normatyvinės galios sąvoka išreiškia Europos sugebėjimą taikiomis priemonemis skleisti savo pagrindines vertybes už ES ribų. Tai tokia galia, kuri, realizuodama save per idejas ir nuomones, yra pajejgi pakeisti "normalumo" sampratą tarptautiniuose santykiuose ${ }^{37}$. ES, bendraudama su kitomis Sajungos naremis ir su valstybėmis, nepriklausančiomis Sajungai,

\footnotetext{
${ }^{30}$ (March and Olsen, 1989: 107), March J., Olsen J. P., "The Institutional Dynamics of International Political Orders", International Organization 52 (4), 1998, p. 943-969)

${ }^{31}$ Shimmelfennig F., "The Community Trap: Liberal Norms, Rhetorical Action, and the Eastern Enlargement of the European Union", International Organization 55(1), 2001, p. 47-80.

${ }^{32}$ Sjursen H., "Introduction: Enlargement and the Nature of the EU Polity" in Sjursen,H., ed., Questioning EU Enlargement: Europe in Search of Identity. London and New York: Routledge, p. 1-15.

${ }^{33}$ Lasas, 1 išnaša.

${ }^{34}$ Shimmelfennig, 31 išnaša, p. 77 ("Once caught in the community trap can be forced to honor identityand value-based commitments").

${ }^{35}$ Riddervold M., Sjursen H., "The Importance of Solidarity: Denmark as a Promoter of Enlargement" in Sjursen H., ed., Questioning EU Enlargement: Europe in Search of Identity, London and New York: Routledge, 2006, p. 81-103.

${ }^{36}$ Manners I., "Normative Power Europe: a Contradiction in terms?", Journal of Common Market Studies 40(2), 2002, p. 235-58; Manners I., "Normative Power Europe Reconsidered: Beyond the Crossroads", Journal of European Public Policy 13, 2006, p. 182-199; Diez T., "Constructing the Self and Changing Others: Reconsidering 'Normative Power Europe", Millennium: Journal of InternationalStudies 33 (3), 2005, p. 613-636; Sjursen, 32 išnaša;

Scheipers S., Sicurelli D., "Normative Power Europe: A Credible Utopia?", Journal of Common Market Studies 45, 2007, p. 435-457; Brommesson, 8 išnaša.

${ }^{37}$ Manners, 2002, 36 išnaša , p 239.
} 
orientuojasi į liberalizmo normas ir principus, suteikdama prioritetą individo teisèms. Tai atsispindi jos oficialiuose dokumentuose. Kalbėdama su pasauliu normatyvinėmis sąvokomis, ES per Aš/Kitas priešpriešą konstruoja save kaip ypatingą, skirtingą nuo kitų egzistuojančių politinių formų instituciją, kurios tapatybè ,ipareigoja normatyviniam elgesiui““38.

Europos kaip normatyvinès galios naratyvo branduolį sudaro liberalios demokratijos principai (demokratija ir įstatymo viršenybè, pagarba žmogaus teisèms ir fundamentalioms laisvèms) ${ }^{39}$. Sis naratyvas kuria tarptautinę ES tapatybę, kurios paskirtis - pagricsti ES poveiki pasaulio tvarkai, universalizuoti normatyvini ES pagrindą. Jame kritiškai vertinama Europos praeitis, ypač II pasaulinio karo patyrimas, o Europos integracija konceptualizuojama kaip saugumo bendruomenių plètra ir kaip naujoji regionalizacija, kurianti bendrą tapatybę ir skatinanti ES normų ir vertybių plètrą visame pasaulyje. Ši gimstanti tapatybè nẻra nacionalinių tapatybiu suma, jos pagrindas -bendri principai ir normos.

Su ES kaip normatyvinès galios tarptautinès tapatybės konstravimu yra susijusi 2003 metais inicijuota ir 2004 metais patvirtinta Naujos kaimynystės politika (NKP). Jos strategijos pranešime rašoma: „Sajungos pagrindas yra pagarbos žmogaus orumui, laisvès, demokratijos, lygybės, įstatymo viršenybès ir pagarbos žmogaus teisèms vertybès. Šios vertybès yra bendros visoms valstybėms narėms....Santykiuose su platesniu pasauliu Sajungos tikslas - puoselèti ir skleisti šias vertybes" ${ }^{40}$ (išskirta G. M.). Bendradarbiavimo su kaimyninėmis valstybėmis pobūdis priklauso nuo jų pasiektų rezultatų igyvendinant šias vertybes, t. y. kaimynystès politika grindžiama jau išmėgintu sąlygiškumo principu, tačiau jis nesiejamas su narystės ES perspektyva.

Baltijos valstybėms tapus Europos Sajungos ir NATO narėmis, iškilo uždavinys naujai suformuluoti pagrindinius užsienio ir saugumo politikos tikslus bei surasti savo vietą Europos Sajungos bendroje užsienio ir saugumo

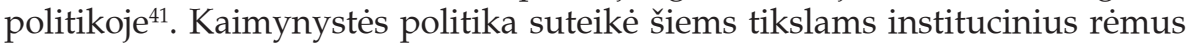
bei naują turini juc tarptautinės tapatybės konstravimui. Baltijos valstybės entuziastingai imasi ES normatyvinès galios ambasadorių posovietinëje erdvëje vaidmens. Svarbia Baltijos valstybiu užsienio politikos kryptimi tampa bendradarbiavimas su Europos Komisijos raporte įvardytomis buvusiomis sovietinėmis respublikomis Ukraina, Baltarusija, Moldova, Armėnija, Gruzija ir Azerbaidžanu.

Tačiau rytinė ES NKP kryptis taip pat yra svarbi Rusijos užsienio politi-

\footnotetext{
${ }^{38}$ Ten pat, p. 242.

${ }^{39}$ Treaty of European Union, http://europa.eu.int/en/record/mt/top.html, 20012011

${ }^{40}$ Commission of the European Communities: Communication from the Commission.European Neighborhood Policy. Strategy Paper, COM(2004) 373 final. Brussels, 12 May 2004.

${ }^{41}$ Nekrasas E., "Lithuanian Foreign Policy: Concepts, Achievements and Predicaments", Lithuanian Foreign Policy Review 2004, 2005, p. 28-37; Galbreath D.J., "Latvian Foreign Policy after Enlargement: Continuity and Change",Cooperation and Conflict: Journal of the Nordic International Studies Association 41 (4), 2006, p. 443-462; Lopata R., „Debatai dẻl Lietuvos užsienio politikos“, Politologija 57 (1), 2010, p. 125-136.
} 
kos interesų sritis ${ }^{42}$. ES ir Rusija konkuruoja dèl įtakos kaimyninėse valstybėse. Baltijos valstybės, noriai prisiimdamos šios konkurencijos priemonės vaidmeni, suaktyvino Rusijos, kaip „Europos Kito“ (European Other) tapatybės, konstravimą. Rusijos sugrèsminimas išlieka esminis Baltijos valstybių politinio diskurso motyvas ${ }^{43}$, ypač jų spartaus ekonominio kilimo laikotarpiu 2003-2007 metais. Nuolatos yra keliami Sovietų Sajungos okupacijos tragiškų pasekmių moralinio ivertinimo bei žalos atlyginimo klausimai ${ }^{44}$, baiminamasi, kad priklausomybė nuo Rusijos energetinių ištekliu gali virsti jos įtaka šalių vidaus politikai bei grèsme nacionaliniam saugumui. Rusijos sugrèsminimas virsta politiniais sprendimais - Lietuvos Seimas prièmé rezoliuciją, reikalaujančią atlyginti sovietinės okupacijos žalą; 2005 metais Estijos ir Lietuvos prezidentai atsisakẻ dalyvauti Rusijos pergalès II pasauliniame kare 60-mečio minėjimo iškilmėse Maskvoje ${ }^{45}$, visos Baltijos valstybės pasmerkẻ Rusiją ir aktyviai rẻmė Gruziją jos konflikte su Rusija 2008 metais. Baltijos valstybių europarlamentarai kartu su kitų Rytų ir Centrinès Europos valstybių parlamentarais nuolatos kelia Rusijos (Sovietų Sajungos) atsakomybės dèl milijonu prarastų gyvybių klausimus ${ }^{46}$. Baltijos valstybès kartu su kitomis Rytų Europos naujokèmis siūlo senosioms Europos valstybėms blaiviai pažvelgti į Rusiją, liautis romantizavus jos gaivališkumą ir neprognozuojamumą, o įvertinti potencialius pavojus, slypinčius demokratijos apribojimuose bei imperinėse ambicijose.

Baltijos valstybės, traktuodamos Rusiją kaip europinių standartų neatitinkančią valstybę, konstruoja ir stabilizuoja savo kaip tautinių valstybių tapatybę. Kita vertus, išreikšdamos „,isipareigojimus Europos centrui“ bei demonstruodamos pasiryžimą "ginti Europos vertybes prieš visą likusį pasaulį ‘47, jos konstruoja europinę tapatybę, t. y. europeizuojasi ${ }^{48}$. Ši iš pirmo žvilgsnio paradoksali europeizacija mes/jie logikos rèmuose yra susijusi su NKP specifika.

\footnotetext{
42 Jakniūnaitė D., "Neighbourhood Politics of Baltic States: between the EU and Russia” in Berg E., Ehin P., eds., Identity and Foreign Policy: Baltic -Russian Relations and European Integration, Farnham: Ashgate, 2009, p.117-131.

${ }^{43}$ Malksoo M., "From Existential Politics Towards Normal Politics? The Baltic States in the Enlarged Europe", Security Dialogue 37 (3), 2006, p. 275-297.

${ }^{44}$ Symposium of the Commission of the Historians of Latvia. "The Hidden and Forbidden History of Latvia under Soviet and Nazi Occupations, 1940-1991", Selected Research of the Commission of the Historians of Latvia 14, 2005, Riga: Institute of the History of Latvia.

${ }^{45}$ Onken E.K., "Commemorating 9 May: The Baltic States and European memory Politics", in Berg, 42 išnaša, p. 33-50.

462004 metais europarlamentaru Vytauto Landsbergio, Bronislawo Geremeko, Valdžio Dombrovskio, Toomas'o Hendriko Ilveso „Deklaraciją dèl 1939 m. rugsejjo 17 d. paminejjimo“ (Declaration on the anniversary of 17 September 1939) pasirašè 86 parlamentarai, tačiau to neužteko, kad ji būtu priimta. Joje keliamos idejjos buvo plètojamos 2008 metų Prahos deklaracijoje (Praque Declaration on European Conscience and Communism ) bei ESBO Vilniaus deklaracijoje (2009). Šiose deklaracijose siūloma Europos Parlamentui paskelbti rugpjūčio 23 dieną totalitarinių ir autoritarinių režimų aukų atminimo diena. 2010 metais Lietuvos Seimas prièmė îstatymą, numatantị kriminalines bausmes už viešą tarptautinių nusikaltimų pateisinimą arba neigimą, tarp jų nusikaltimų, kuriuos įvykdė Sovietų Sajunga ir nacistinè Vokietija prieš Lietuvą.

${ }^{47}$ Brommesson, 8 išnaša, p. 228.

${ }^{48}$ Malksoo M., „Liminality and Contested Europeanness: Conflicting Memory Politics in the Baltic Space“ in Berg, 42 išnaša, p. 65-83.
} 
Kaip pažymi Pertti Joenniemi, Europos Sajungai tampant tradiciniu, vieningu, tautinę valstybę primenančiu veikèju, kaimynystès politika atlieka europinès erdvės pertvarkymo vaidmeni, skatindama jos diferenciaciją. „Akivaizdu, kad pastaraisiais metais kaimynystės politika, neigaudama aiškios formos, sujungė savyje ir įtraukties, ir atskirties elementus " ${ }^{49}$. Baltijos valstybės, kritikuodamos NKP už tai, kad ji nesuteikia kaimyninėms valstybėms narystės ES perspektyvos, siekia įveikti ši jos dvilypumą.

Nors visos Baltijos valstybės dalyvavimą NKP laiko svarbiu įsitraukimo į ES bendrą užsienio ir saugumo politiką būdu, tačiau jų dalyvavimo intensyvumas skiriasi. Ekonominio pakilimo laikotarpiu jos mielai atsiliepdavo šaukiamos „Baltijos tigrais“ ir buvo pasiryžusios savo sėkmès receptais pasidalyti su kitomis valstybėmis. Aktyviausia ir ambicingiausia šiame mokytojos vaidmenyje kuri laiką buvo Lietuva, pasyviausia - Latvija. Estija laikẻ save technologiškai pirmaujančia valstybe, ypač plètojant komunikacines technologijas ir kuriant elektroninę vyriausybę. Latvija, igyvendindama „naujų galimybių ir pragmatizmo ${ }^{\prime 50}$ politikos tikslus, daugiausia dèmesio NKP skyrè ekonominiams ir tarpvalstybiniams sienos kirtimo klausimams.

Lietuvos įsitraukimas į NKP buvo lydimas naujo šalies - regiono centro įvaizdžio konstravimu. Faktiškai beveik visuose 2004-2006 metų oficialiuose su užsienio ir saugumo politika susijusiuose dokumentuose ir oficialiose kalbose pabrèžiama, kad Lietuva siekia tapti ,aktyviu ir patraukliu tarpregioninio bendradarbiavimo centru, skleidžiančiu euroatlantines vertybes, tolerancijos ir bendradarbiavimo dvasią, jungiančiu kultūras ir civilizacijas "51 . Lietuvos ambicingą užsienio politiką kai kurie kultūrologai bei istorikai aiškina jos šlovingos praeities įtaka ${ }^{52}$ : 15-16 amžiuje Baltarusija ir dalis Ukrainos įejo į Lietuvos Didžiosios Kunigaikštystès sudèti, kelis šimtmečius egzistavo bendra Lenkijos ir Lietuvos Valstybė (1569-1795). Lietuvos kaip regiono lyderès vaidmuo įpareigoja ją „,būti tvirta Vakarų demokratijos vertybių ir saugumo plètros advokate, remiančia Europos keliu siekiančias eiti valstybes ${ }^{\prime 53}$. Lietuvos politiniame diskurse Europos kaip normatyvinès galios naratyvas transformuojasi į Lietuvos kaip regiono centro tapatybės konstravimą ${ }^{54}$. Konstruodama šalies - regiono centro tapatybę, Lietuva orientavosi į normatyvinį modelį, įpareigojanti, tariant prezidento Adamkaus žodžiais, moraliai, grindžiamai principais, o ne vienadieniais interesais, užsienio politikai. Palaipsnis regiono centro tapatybės atsisakymas sutapo su pragmatizmo tendencijų stiprëjimu šalies užsienio politikoje.

Kitų Baltijos valstybių tapatybės konstravime taip pat atsispindi pana-

\footnotetext{
${ }^{49}$ Joenniemmi P., „Turning into a Sovereign Actor? Probing the EU through the Lens of Neighbourhood?” Geopolitics, (forthcoming).

${ }^{50}$ Spruds A., "Entrapment in the discourse of Danger? Latvian-Russian Interaction in the Context of European Integration", in Berg, 42 išnaša, p. 113.

${ }^{51}$ Dèl pagrindinių valstybès užsienio politikos tikslų ir uždavinių 2004-2008 metais. Lietuvos politinių partijų susitarimas, http://www.urm.1t/popup2.php?item_id=158, 20101219.

${ }_{52}$ Beresnevičius G., Imperijos darymas, Vilnius: VU leidykla, 2003.

${ }^{53}$ Lietuvos Respublikos Prezidento Valdo Adamkaus metinis pranešimas, 2005.

${ }^{54}$ Miniotaite G., ,Europos normatyvinè galia ir Lietuvos užsienio politika“, Politologija 43 (3), p. 3-19.
} 
šios tendencijos. Tarpukario aukso amžiaus naratyvas yra keičiamas nauja sèkmès istorija, kurioje pagrindinis vaidmuo tenka ekonominèms reformoms ir informacinei visuomenei. Mesdamos iššūkį Europos centrui, Baltijos valstybès atmeta joms primestą mokinukių vaidmeni, jos - pažangos nešèjos i Rytus, siūlančios ES kelius, vedančius toliau į Rytus ${ }^{55}$. Ekonominės krizès laikotarpiu „Baltijos tigrams" virstant „kačiukais“ jos tęsè rytų politiką, aktyviai įsitraukdamos į naujujų ES iniciatyvų - Rytų partnerystès ir Baltijos jūros valstybiu strategijos igyvendinimą. Ju, kaip perëjimo į demokratiją mokytoju, vaidmuo pasipildè krizès įveikimo patyrimu. Neatsitiktinai Taline 2011 metų pradžioje buvo įsteigtas Rytų partnerystès mokymo centras. Baltijos valstybės siekia, kad Rytu partnerystės politika būtų papildyta ES narystès perspektyvos suteikimu to siekiančioms valstybèms ${ }^{56}$.

Baltijos valstybès, siekdamos tapti lygiavertèmis bendros ES užsienio ir saugumo politikos dalyvėmis, netruko pastebèti, kad tos politikos bendrumas labiausiai joms rūpimoje santykių su Rusija srityje tẻra tik gera intencija, kurią žlugdo skirtingi valstybių interesai. Buvo akivaizdu, kad Rusijai leidžiama savaip traktuoti naująsias ir senąsias ES valstybes. Beveik tuo pačiu metu ji sudarè nepalankią Baltijos valstybėms sutartį su Vokietija dẻl dujotiekio Šiaurés srautas (Nord Stream) tiesimo ir uždarè naftotiekį, tiekiantį naftą Lietuvos naftos perdirbimo gamyklai.

Pažymètina, kad Baltijos valstybės nėra vieningos santykiuose su Rusija. Artimiausia senujų Europos valstybiu pozicijai yra Latvija. Ji vienintelè iš Baltijos valstybių pozityviai įvertino Šiaurès srovès projektą bei užėmè nuosaikią poziciją įvykiu, susijusių su "bronzinio kareivio“ istorija Taline 2007 metais, atžvilgiu. Lietuva santykių su Rusija problemų sprendimą siekia perkelti į europinį lygị. Nepaisant priklausomybės nuo Rusijos dujų ir naftos, ji stengiasi užtikrinti jų tiekimą ne stiprindama dvišalius santykius su Rusija, o mėgindama daryti įtaką ES - Rusijos santykiams. 2008 metais Lietuva palaikè Lenkijos veto dèl Rusijos-ES partnerystès ir bendradarbiavimo sutarties pasirašymo, reikalaudama papildyti sutartį Baltijos valstybių energetinio saugumo garantijomis. Pakitus Lenkijos pozicijai, Lietuva liko vienintelè ES valstybė, kritiškai vertinanti susitarimą. Lietuvos mėginimai igyvendinti ES energetikos politikos direktyvas, įpareigojančias liberalizuoti energetikos rinką, atskiriant dujų tiekimo ir perdavimo sistemos valdymą, sulaukè didžiausios „Lietuvos duju“ akcininkès „Gazprom" ir Vokietijos E.ON pasipriešinimo - Lietuva už gamtines dujas moka brangiau negu bet kuri ES valstybè. Latvijai ir Estijai, lanksčiau traktuojančioms ES direktyvas, pavyko išsiderèti žemesnę duju kainą. Tolesnejje perspektyvoje Lietuvos méginimai demonopolizuoti energetikos rinką turètų ekonomiškai pasiteisinti, tačiau tik tuo atveju, jei visos ES

\footnotetext{
${ }^{55}$ Smith D., ed., The Baltic States and their Region: New Europe or Old?, Amsterdam, New York: Rodopi, 2005.

${ }^{56}$ Priešingos pozicijos laikosi Lenkija ir Švedija, 2010 metais jų užsienio reikalų ministrų laiške ES viceprezidentei Catherine Ashton pareiškiama, kad ES plètra buvusių sovietinių respublikų sąskaita yra neimanoma.
} 
valstybès šiuo klausimu laikytųsi vieningos pozicijos .

Visose Baltijos valstybėse išryškejja nusivylimo Europos Sajungos nesugebejjimu (nenoru?) kalbèti vienu balsu nuotaikos ${ }^{57}$. Vytautas Landsbergis išreiškẻ ši nusivylimą jam būdinga radikalia forma: „ES yra prarasta. Mano nuomone, ji nepajègi ir iš tiesų net nemėgina surasti fundamentalesni savo egzistencijos ir ateities pagrindą ${ }^{\prime 58}$. Gal todėl Baltijos valstybėse sustiprëjo pragmatinės užsienio politikos tendencijos, kurios pasireiškè nuosaikesne pozicija Rusijos atžvilgiu bei posūkiu ị aktyvesnį ES regioninès politikos palaikymą. 2010 metais Pergalès dienos minejjime Maskvoje dalyvavo ne tik Latvijos, bet ir Estijos prezidentas. Abu prezidentai išreiškè pritarimą ES - Rusijos strateginès partnerystės sutarčiai. 2010 metu pabaigoje sėkmingai praejjo Latvijoje jau vadinamas istoriniu prezidento Valdžio Zatlero oficialus vizitas į Rusiją. Ir Lietuvos prezidente, ir ministras pirmininkas nevengia asmeninės diplomatijos santykiuose su Vladimiru Putinu ir Dmitrijumi Medvedevu. Taip pat tam turi įtakos 2009-2010 metais išryškèjęs JAV-Rusijos santykių atšilimas bei Lenkijos suartejjimas su Rusija.

Šalia Rusijos „demaskavimo“ ir jos ambiciju tramdymo, siekiant vieningos ES užsienio ir saugumo politikos ne mažiau svarbiu savo uždaviniu Europos Sajungoje Baltijos valstybès laiko euroatlantinių ryšių stiprinimą. 2003 metais JAV gynybos sekretoriaus Donaldo Rumsfeldo priskirtos „naujajai“, Europai, jos buvo ir išlieka nuosekliomis JAV užsienio politikos šalininkèmis. Baltijos valstybės, kaip „Vilniaus dešimtuko" narès, pritarė JAV antiteroristinèms iniciatyvoms po rugsèjo 11-osios, jos palaiko JAV politiką Irake ir Afganistane. Stephenas Mullas, buvęs JAV ambasadorius Lietuvoje, Baltijos valstybiu ir Lenkijos proamerikietišką laikyseną apibrèžė kaip naujų ES narių balsą, kuris su pasitenkinimu girdimas Vašingtone ir kurio negali ignoruoti Briuselis. Nepaisant kintančių aplinkybiu, Baltijos valstybės neatsisako Rytu Europos stabilizavimo ir transatlantinio ryšio stiprinimo vaidmens ${ }^{59}$. Teigiamai vertindamos ES pastangas stiprinti karinę saugumo dimensiją, jos ir toliau savo saugumą sieja su tvirto transatlantinio ryšio išlaikymu. Tačiau, prasidèjus prezidento Barako Obamos erai ir susilpnejus JAV kaip Baltijos valstybiu saugumo garanto prestižui, jos vis daugiau reikšmės teikia Baltijos ir Šiaurès šalių bendradarbiavimui saugumo srityje $\mathrm{e}^{60}$.

\footnotetext{
${ }^{57}$ Vitkus G., „Dabartinis Europos Sajungos ekonominès ir politinės integracijos etapas - kaip spręsti „sendaikčio“ dilemą?“, Politologija 55 (3), 2009, p. 3-29; Plakans A., „Latvia: Normality and Disappointment", East European Politics \& Societies 23 (4), 2009, p. 518-525.

${ }^{58}$ Landsbergis V., "The European Union is Lost", Lithuania Tribune, 2010/10/07.

http://www.lithuaniatribune.com/2010/10/07/the-european-union-is-lost-prof-landsbergis/, 20101210

${ }^{59}$ Urbelis V., 2003. "Changes in the US Global Security Strategy and its Implications for Lithuania", Lithuanian Annual Strategic Review 2002, 2003, p. 37-68.

${ }^{60} 2011$ metu pradžioje prezidentė Dalia Grybauskaitė pabrèžè, kad ,glaudūs Šiaurès ir Baltijos šalių tarpusavio santykiai yra Lietuvos užsienio politikos prioritetas“. http://www.lrp.lt/lt/spaudos_centras_392/ pranesimai_spaudai/glaudus_baltijos_ir_siaures_saliu_bendradarbiavimas_uztikrins_sekminga_regiono_ ateiti.html, 20110223
} 


\section{Vietoje išvadų}

Trumpai apžvelgus Baltijos valstybių užsienio ir saugumo politikos europeizacijos tendencijas, tikslinga grižti prie pirmame skyriuje pateiktos lentelès, papildant ją Baltijos valstybių charakteristikomis.

2 lentelè. Baltijos valstybių užsienio ir saugumo politikos europeizacija

\begin{tabular}{|c|c|c|c|}
\hline & Europeizacija & $\begin{array}{l}\text { Nacionalinè užsienio ir } \\
\text { saugumo politika }\end{array}$ & $\begin{array}{c}\text { Baltijos valstybių (BV) } \\
\text { užsienio ir saugumo } \\
\text { politika } \\
\end{array}$ \\
\hline \multirow{4}{*}{1.} & \multirow{2}{*}{$\begin{array}{l}\text { ES projekcija, } \\
\text { valstybejs } \\
\text { prisitaikymas } \\
\text { ir politikos } \\
\text { suartèjimas (iš } \\
\text { viršaus) }\end{array}$} & $\begin{array}{l}\text { Didëjanti politinè centro } \\
\text { įtaka }\end{array}$ & Acquis prièmimas \\
\hline & & Bendrų tikslų prièmimas & $\begin{array}{l}\text { Dalyvavimas igyvendinant } \\
\text { ŠDI, Naujos kaimynystės, } \\
\text { Rytu partnerystės, Baltijos } \\
\text { jūros valstybių strategiją }\end{array}$ \\
\hline & \multirow{2}{*}{$\begin{array}{l}\text { Valstybės narès } \\
\text { prisiderinimas } \\
\text { prie ES narystės } \\
\text { reikalavimu }\end{array}$} & $\begin{array}{l}\text { Bendros politikos } \\
\text { viršenybė }\end{array}$ & $\begin{array}{l}\text { BV Užsienio ir saugumo } \\
\text { politikos prioritetai atitinka } \\
\text { BUSP kryptis }\end{array}$ \\
\hline & & $\begin{array}{l}\text { ES normu ir politikos } \\
\text { internalizacija }\end{array}$ & $\begin{array}{l}\text { BV užsienio politikos } \\
\text { pagrindimas atitinka ES } \\
\text { vertybines nuostatas }\end{array}$ \\
\hline \multirow{4}{*}{2.} & \multirow{2}{*}{$\begin{array}{l}\text { Nacionalinè } \\
\text { projekcija (iš } \\
\text { apačios) }\end{array}$} & $\begin{array}{l}\text { Valstybė siekia padidinti } \\
\text { savo įtaką pasaulyje }\end{array}$ & $\begin{array}{l}\text { BV kaip demokratizacijos } \\
\text { mokytojos posovietinėje } \\
\text { erdvėje } \\
\text { Suartëjimas su Šiaurès } \\
\text { valstybèmis } \\
\text { Lietuva - pretenzijos būti } \\
\text { regiono centru }\end{array}$ \\
\hline & & $\begin{array}{l}\text { Valstybė siekia daryti } \\
\text { ìtaką kitų ES valstybių } \\
\text { užsienio politikai }\end{array}$ & $\begin{array}{l}\text { NORD Stream kritika, } \\
\text { parama JAV-Irako } \\
\text { konflikte, parama Gruzijai } \\
\text { konflikte su Rusija, } \\
\text { euroatlantinių ryšių } \\
\text { stiprinimas }\end{array}$ \\
\hline & \multirow[t]{2}{*}{$\begin{array}{l}\text { Nacionalinès } \\
\text { valstybès iitaka ir } \\
\text { indėlis į BUSP }\end{array}$} & $\begin{array}{l}\text { Valstybė naudoja } \\
\text { ES kaip apsauginį } \\
\text { skyda, kad pateisintur } \\
\text { nepopuliarius UP } \\
\text { žingsnius }\end{array}$ & $\begin{array}{l}\text { ES energetikos politikos } \\
\text { reikalavimais pateisinama } \\
\text { išaugusi įtampa } \\
\text { santykiuose su Rusija } \\
\text { (Lietuva) }\end{array}$ \\
\hline & & $\begin{array}{l}\text { Perkèlimas nacionalinès } \\
\text { užsienio politikos tikslų } \\
\text { į ES lygi }\end{array}$ & $\begin{array}{l}\text { BV siekia bendros ES } \\
\text { energetikos politikos } \\
\text { bei vieningo požiūrio i̇ } \\
\text { santykius su Rusija }\end{array}$ \\
\hline
\end{tabular}

Sudaryta autorés 
Kaip matyti iš lentelès, Baltijos valstybių užsienio ir saugumo politikos europeizacija vyksta kaip viršaus (ES centro direktyvos) ir apačios (valstybiu narių iniciatyvos) sąveikos procesas. Trumpa USP raidos apžvalga leidžia teigti, kad siekiant ES narystès vyravo pragmatinè orientacija į centro nuostatas; sąlygiškumo principas reikalavo ne tik vidaus politikos demokratizavimo, bet ir atsižvelgti į BUSP kryptis ir principus. Baltijos valstybėms tapus ES narèmis, pragmatinė ES interpretacija išlieka, įsipareigojimai centrui praeina pro nacionalinių interesu prizmę. Sustiprèja valstybių pastangos daryti poveikį ES bendrai užsienio ir saugumo politikai, perkeliant nacionalinius interesus į ES lygį.

Baltijos valstybių užsienio ir saugumo politikos europeizacijos procesas yra neatsiejamas nuo valstybės tapatybės konstravimo. Šiam procesui yra būdinga įtampa tarp tautinès valstybès tapatybès (išreiškiamos tilto, Vakarų civilizacijos placdarmo ir avanposto metaforomis) ir europinès tapatybès, kuri yra siejama su bendra politine kultūra bei integraciniais užsienio ir saugumo politikos tikslais. Viena vertus, kaip tautinès valstybės Estija, Latvija ir Lietuva pabrèžia savo išskirtinumą ir nacionalinio saugumo poreikius. Kita vertus, kaip Europos dalis jos kartu su kitomis ES valstybèmis siekia formuoti „normalumo“ sampratą tarptautiniuose santykiuose.

Tapusios ES narèmis, Baltijos valstybės sustiprino Rusijos sugrėsminimo retoriką, traktuodamos ją kaip nesaugią ir neprognozuojamą valstybę. Jos, ypač Lietuva $^{61}$, siekia įtikinti kitas ES valstybes, kad „ypatingas" rusiškasis kelias i demokratiją bei jos užsienio politikos imperinės ambicijos kelia grèsmę ne tik Baltijos valstybėms, bet ir egzistuojančiai pasaulio tvarkai. Šiame kontekste Baltijos valstybiu santykiai su Rusija gali būti vertinami kaip nuoseklus Europos normatyvinès galios, taikiomis priemonèmis plečiančios „normalios politikos“ erdvę, tapatybės igyvendinimas. Būdamos aktyviomis ES naujos kaimynystès bei Rytų partnerystės politikos dalyvėmis, Baltijos valstybės ragina ES laikytis atviru durų politikos kaimyninių šalių rytuose atžvilgiu, tokiu būdu konstruodamos savo kaip europietiškų - demokratiniu, civilizuotų ir civilizuojančių - valstybiu, tikruju Europos normatyvinės galios ambasadoriu, tapatybę.

Baltijos valstybių užsienio ir saugumo politikos dvilypume tarsi iškreiptame veidrodyje atsispindi ES BUSP nenuoseklumas. ES ir šiandieną tebèra aiškiai „neidentifikuotas politinis objektas“62, besiblaškantis tarp „Vestfalijos supervalstybės ir viduramžių imperijos" "63. Tam tikra prasme Baltijos valstybių užsienio ir saugumo politika yra nuoseklesnè negu Europos Sajungos. ES kaimynystės politikoje jos pabréžia ne pragmatini, o normatyvinį aspektą, ragindamos rimtai traktuoti Europos vertybinius pagrindus.

\section{1 m. balandis}

\footnotetext{
${ }^{61}$ Šios Rusijos grèsmès akcentavimo tendencijos ypač aiškiai išreikštos prezidento Valdo Adamkaus ir Vytauto Landsbergio 2010-2011 metų interviu ir publikacijose.

${ }_{62}$ Jacques Delors. Cituojama pagal: Zielonka J., Europe as Empire: The Nature of the Enlarged European

Union, Oxford: Oxford University press, 2006, p. 4.

${ }^{63}$ Ten pat, p. 12 (Westphalian superstate and neo-medieval empire).
} 